\title{
The Relationship between Adolescent Risk Behavior in Drug Abuse: A Literature Review
}

\author{
Ahmad Yani ${ }^{1}$, Sukri Palutturi ${ }^{2}$, Ridwan Amiruddin ${ }^{3}$, Sudirman Nasir ${ }^{4}$, \\ Aminuddin Syam ${ }^{5}$, Rajindra ${ }^{6}$, Anto J. $\mathrm{Hadi}^{7}$ \\ ${ }^{1}$ Doctoral Student, Faculty of Public Health, Hasanuddin University, Indonesia, ${ }^{1}$ Lecturer, Faculty of Public \\ Health, Universitas Muhammadiyah Palu, Indonesia, ${ }^{2}$ Professor, Department of Health Policy and Administration, \\ Faculty of Public Health, Universitas Hasanuddin, Indonesia, ${ }^{3}$ Professor,Department of Epidemiology, Faculty \\ of Public Health,Hasanuddin University, Indonesia, ${ }^{4}$ Senior Lecturer,Department of Health Promotion, Faculty \\ of Public Health, Hasanuddin University, Indonesia, ${ }^{5}$ Senior Lecturer, Departement of Nutrition Science, Faculty \\ of Publlic Health, Hasanuddin University, Makassar, ${ }^{6}$ Senior Lecturer, Departemen of Management, Faculty of \\ Economics, Universitas Muhammadiyah Palu, ${ }^{7}$ Senior Lecturer, Departement of Nutrition Science, Faculty of \\ Publlic Health, Universitas Aufa Royhan, Padangsidimpuan, Indonesia
}

\begin{abstract}
This review aimed to explore the relationship between risk behaviors and drug abuse in adolescents. This review was reported according to PRISMA guidelines (Selected Reporting Items for Systematic Review). A review protocol was developed to identify all articles published investigating the relationship between Adolescent Risk Behavior and Drug Abuse. Relationship between risk behavior and drug abuse among adolescents; some studies measured the risk behaviors of adolescent drug users. Other studies intervened to prevent risk behaviors in adolescents related to drug abuse. At the same time, some studies found no significant relationship between drug-related behavior and drug abuse. Limitations on methodology are significant in organizing the literature to see connections. This review concludes that all deviant behavior is highly risky for adolescent health. Attitudes toward risk behavior refer to adolescents' perception of vulnerability to the possible negative consequences of unsafe behavior.
\end{abstract}

Keywords: Risk Behavior; Drug Abuse; systematic literature review; Adolescents.

\section{Introduction}

Given the high prevalence of drug abuse among adolescents $^{(1,2)}$, many studies support to prevent risky behavior of adolescents in preventing risky behavior in drug abuse ${ }^{(3-7)}$. Depression and school environment factors most influence drug users among adolescents. In contrast, psychological and peer environment factors become pivotal domains to be targeted in programs to prevent drug use in adolescents. ${ }^{(8-12)}$ Targeting

\footnotetext{
Corresponding Author:

Ahmad Yani

Doctoral Student, Faculty of Public Health, Hasanuddin University, Indonesia

e-mail: ahmadyani.publichealth@gmail.com
}

adolescents is crucial because early on, they can build their intention not to behave riskily about drug abuse $\mathrm{e}^{(13,14)}$ The role of family, peers, school, and community is very supportive in preventing risky behavior in adolescents. Risk behavior prevention programs that target early teens in social contexts can also equip their knowledge and skills to avoid risky behavior. In this way, adolescents may need a more integrated approach to prevention that targets various adolescent life settings from multiple forms of risk behavior. ${ }^{(15)}$

Risk behavior is controlled intentionally or unintentionally to the perceived uncertainty about how the results will be in the future. Risk-taking behavior can be said to be voluntary behavior that is not socially acceptable with potentially harmful effects because precautions are not taken, such as drug abuse ${ }^{(16)}$. in Theory of Planned Behavior that a positive attitude 
that needs to be fostered through the perspective of perception of behavioral control to produce intentions in positive behavior, in this case, prevents him from using drugs (Ajzen, 1991).

This study focuses on adolescents aged less than 20 years as subjects in this study. Various damage caused to adolescents who consume drugs, not only physical but mental, social, their future is at stake. For this reason, this review aimed to explore the relationship between risk behaviors towards drug abuse in adolescents.

\section{Method}

This review was reported according to PRISMA guidelines (http://www.prisma-statment.org) Selected Reporting Items for Systematic Review). A review protocol was developed to identify all articles published that investigate the relationship between Adolescent Risk Behavior and Drug Use. The following search terms were used: (("adolescent" [MeSH Terms] OR "adolescent"[All Fields]) AND ("risk behaviour"] [All Fields] OR "risk-taking"[MeSH Terms] OR "risktaking"[All Fields] OR ("risk"[All Fields] AND "behavior"[All Fields]) OR "riskbehavior" [All Fields]) AND ("substance-related disorders"] [MeSH Terms] OR ("substance-related"[All Fields] AND "disorders"[All Fields]) OR "substance-related disorders"[All Fields] OR ("drug"'[All Fields] AND "abuse"[All Fields]) OR "drug abuse"[All Fields])) AND (Journal Article[ptyp] AND "loattrfree full text" [sb] AND "2009/12/15”[PDat] : “2019/12/12”[PDat]) AND ((Journal Article[ptyp] OR Observational Study[ptyp]) AND “loattrfreefull text"[sb] AND "2009/12/15"[PDat] : “2019/12/12”[PDat].

Search strategy and data sources: There were three steps to find articles in this study. The first step was with the help of research librarians. A search was then done through the Web of Science, Pubmed, and the Scopus database to analyze text words in titles, abstracts, and keywords in the last ten years (2009-2019). After this analysis, the final keywords related to Adolescent Risk Behavior and Drug Abuse were chosen, and a search strategy was developed through the relevant database.
The second step was an electronic search carried out with a search strategy through 8 electronic bibliographic databases, namely: PubMed, ScienceDirect, Scopus, ProQuest Central, SAGE journal, Emerald Fulltext, EBSCOhost, Web of Science. The search conducted for 1 Month (November 2019). And Third, all relevant references cited in the article were to look for additional related studies manually. All items that had been downloaded were stored in Mendeley's Software. Duplicate reports were excluded, titles and abstracts of all reviews go through a peer-review process. The author checked whether the article included full text or not. After carrying out these steps, the authors examined using the inclusion criteria for the relevance of the item.

Inclusion Criteria: The article was chosen when analyzing the relationship between adolescent risk behavior and drug abuse; use quantitative methodology; adolescents less than 20 years old, available (full text) in English. The age category was chosen based on the adolescent's definition of psychosocial development ${ }^{(18)}$.

Data Extraction: First, a summary table was developed and tested by the author. Then, a summary table, as well as the full text of the selected article, and data extracted manually. Data obtained were article title, year, author, research arrangement, research design, research participant characteristics, measurement of risk behavior in drug abuse in adolescents.

Data Analysis: Data extracted and analyzed were performed narratively. Meta-analysis was not done in this study.

\section{Results}

Articles found in the initial search contained 109 items based on keywords that have been described in the method section. Thirty-three articles were excluded because of the duplication; 76 materials were included in the screening stage. Items that were complete and deemed worthy were 25 . Then 12 articles were excluded, with the reason the results are not relevant. Then 13 reports that met the requirements for review. 
Table 1. Summary of the included studies' findings and authors' conclusions.

\begin{tabular}{|c|c|c|c|}
\hline No & Reference & Results & Authors' conclusions \\
\hline 1 & $(\text { Heger et al., 2014) })^{(19)}$ & $\begin{array}{l}\text { Most risk behaviors tend to be associated } \\
\text { with increased depressive symptoms in } \\
\text { adolescent-related drug abuse and found no } \\
\text { significant impact on depressive symptoms } \\
\text { of adolescents. }\end{array}$ & $\begin{array}{l}\text { Future studies are recommended to explore } \\
\text { the relationship between depression and risk } \\
\text { behavior in adolescents. }\end{array}$ \\
\hline 2 & $\begin{array}{l}\text { (Wojtyla-Buciora et al., 2017) } \\
\text { (20) }\end{array}$ & $\begin{array}{l}\text { Increased drug use among adolescents } \\
\text { in } 2009-2011 \text {, more specifically those in } \\
\text { secondary school. }\end{array}$ & $\begin{array}{l}\text { Teenagers do not have enough knowledge } \\
\text { about the dangers of drugs. In facing } \\
\text { the growing threat of drug trafficking, } \\
\text { prevention efforts in health education are } \\
\text { needed. }\end{array}$ \\
\hline 3 & $\begin{array}{l}\text { (Ammerman, Steinberg and } \\
\text { McCloskey, 2018) }\end{array}$ & $\begin{array}{l}\text { Risky behavior is significantly relevant to } \\
\text { their suicide ideas. }\end{array}$ & $\begin{array}{l}\text { This finding has implications for prevention } \\
\text { and intervention programs for adolescents }\end{array}$ \\
\hline 4 & $\begin{array}{l}\text { (Browning, Soller and } \\
\text { Jackson, 2015) }\end{array}$ & $\begin{array}{l}\text { Strengthening with the environment shows a } \\
\text { strong negative relationship with drug use in } \\
\text { adolescents }\end{array}$ & $\begin{array}{l}\text { The importance of eliminating routines } \\
\text { that are often done in adolescent health and } \\
\text { behavior. }\end{array}$ \\
\hline 5 & $(\text { Keyes et al., 2015) })^{(23)}$ & $\begin{array}{l}\text { The results of this study found that the } \\
\text { magnitude of the relationship between risk } \\
\text { behavior and drug use. }\end{array}$ & $\begin{array}{l}\text { The importance of putting risk behavior in a } \\
\text { framework to prevent drug users. }\end{array}$ \\
\hline 6 & $($ Kellam et al., 2014) & $\begin{array}{l}\text { Reduced high-risk behavior and drug abuse } \\
\text { in men who are in first grade and junior high } \\
\text { school are more influential. }\end{array}$ & $\begin{array}{l}\text { Interventions through classroom-based } \\
\text { prevention can reduce risky behavior in drug } \\
\text { abuse. }\end{array}$ \\
\hline 7 & (Dougherty et al., 2015) ${ }^{(25)}$ & $\begin{array}{l}\text { All adolescents have relatively stable delays } \\
\text { over time in increased risk-taking. }\end{array}$ & $\begin{array}{l}\text { Adolescents in risk-taking can contribute } \\
\text { to increasing their motivation for drug } \\
\text { prevention in adolescents. }\end{array}$ \\
\hline 8 & (Zebrak and Green, 2017) ${ }^{(26)}$ & $\begin{array}{l}\text { Drug users among adolescents have } \\
\text { increased risk behaviors. }\end{array}$ & $\begin{array}{l}\text { For further research to explore more on the } \\
\text { social aspects by linking drug use and risk } \\
\text { behavior. }\end{array}$ \\
\hline 9 & $(Y u$ et al., 2017) & $\begin{array}{l}\text { Some adolescents retain their personalities } \\
\text { from time to time, but they are more likely to } \\
\text { change risky behaviors. }\end{array}$ & $\begin{array}{l}\text { The need for prevention programs through } \\
\text { interventions that are integrated and } \\
\text { specifically designed to prevent risky } \\
\text { behavior towards drug abuse in adolescents. }\end{array}$ \\
\hline 10 & (Cordova et al., 2018) $^{(28)}$ & $\begin{array}{l}\text { Teenagers mostly accept storytelling } \\
\text { Empowerment interventions. }\end{array}$ & $\begin{array}{l}\text { It is hoped that further research will be able } \\
\text { to link interventions carried out with risk } \\
\text { behaviors. }\end{array}$ \\
\hline 11 & $(\text { Gart and Kelly, 2015) })^{(29)}$ & $\begin{array}{l}\text { The results of this study show a statistically } \\
\text { significant effect between adolescent risk } \\
\text { factors for suicide resulting from drug use in } \\
\text { adolescents. }\end{array}$ & Illegal drug use can lead to suicide. \\
\hline 12 & $\left(\right.$ Thombs et al., 2009) ${ }^{(30)}$ & $\begin{array}{l}\text { Their intention (adolescents) when driving a } \\
\text { vehicle with } 60 \text { minutes after leaving work, } \\
70 \% \text { of those who use drugs. }\end{array}$ & $\begin{array}{l}\text { A large number of high-risk behaviors } \\
\text { among adolescents must be a priority focus } \\
\text { for prevention efforts. }\end{array}$ \\
\hline 13 & (Hops et al., 2011a) $)^{(31)}$ & $\begin{array}{l}\text { Specific interventions can reduce risky } \\
\text { behavior in drug abuse for } 18 \text { months of } \\
\text { follow-up in high-risk teens. }\end{array}$ & $\begin{array}{l}\text { Drug abuse prevention interventions can } \\
\text { have preventive effects for teens who are at } \\
\text { risk. }\end{array}$ \\
\hline
\end{tabular}

\section{Discussion}

The purpose of this review was to explore the relationship between risk behaviors towards drug abuse in adolescents. The 13 articles that have been identified in table 1 show that risk behaviors towards health are a variety of activities carried out by people with a frequency or intensity that increases the risk of disease or injury. The term health behavior must be distinguished from risk behavior, which means an action associated with increased susceptibility to certain diseases ${ }^{(32)}$. 
Health risk behaviors are various behavioral engagements carried out by people with an intensity that increases their susceptibility to the risk of disease or injury or may have dangerous consequences. ${ }^{(33)}$. Risk behavior arises from risk factors originating from within adolescents, from family and from outside the family. Factors originating from adolescents are low achievement motivation and low self-esteem. Elements from the family are rigorous parents and little support. From outside the family are relationships with deviant peers and orientation towards excessive peers. ${ }^{(31,34-37)}$ no studies have examined the similarity in risk content (e.g., substance use, sexual behaviors.

All teenagers have the risk to abuse drugs. However, several risk factors of drug abuse among adolescents, such as genetic risk factors are supported by the results of research that adolescents from alcoholic biological parents have 3-4 times the risk of drinking alcohol compared to adolescents from alcoholic adoptive parents, parenting in a vast family its influence on drug abuse in adolescents. The power of close friends to abuse drugs is more significant than in strangers. ${ }^{(38)}$.

In risky behavior, for example, teens feel that they will not be at risk if they do not follow traffic signs. Second, the perception of severity, namely the level of one's belief that the consequences of health problems will become increasingly severe, for example, in risky behavior, adolescents who experience overweight problems will not add to health problems. Protection is needed to protect adolescents from risky behavior and the impact of risk behavior on health. The forms of protection include coping, commitment to achievement, control, and fulfilling developmental tasks. One way of security is the presence of power. With this control, it will prevent students from conducting risky behaviors to health and protect adolescents from the adverse effects of risky behavior on health. A person who has weak selfcontrol will have a higher risk behavior, and if he has high self-control, the lower the risk behavior.

\section{Conclusion}

This review concludes that all deviant behavior is hazardous for adolescent health. Attitudes toward risk behavior referred to as adolescent's perception of vulnerability to the possible negative consequences of risky behavior. Numerous studies show that prototype perceptions are connected with teenagers' decisions about whether they will engage in risky behavior or not.
Attitudes towards health risk behaviors are associated with health risk behaviors, including drug abuse. Therefore, control of behavior is pivotal as individual beliefs in his ability to manage any impulse that arises to behave negatively from within the individual towards channeling a more healthy and positive inspiration.

Ethical Clearance: Taken from University ethical committee

\section{Source of Funding: Self}

\section{Conflict of Interest: Nil}

\section{Reference}

1. Wills TA, Knight R, Williams RJ, Pagano I, Sargent JD. Risk factors for exclusive e-cigarette use and dual e-cigarette use and tobacco use in adolescents. Pediatrics. 2015;135(1):e43-51.

2. Merikangas KR, He J, Burstein M, Swanson SA, Avenevoli S, Cui L, et al. Lifetime prevalence of mental disorders in US adolescents: results from the National Comorbidity Survey ReplicationAdolescent Supplement (NCS-A). J Am Acad Child Adolesc Psychiatry. 2010;49(10):980-9.

3. Caldwell CH, Rafferty J, Reischl TM, De Loney EH, Brooks CL. Enhancing parenting skills among nonresident African American fathers as a strategy for preventing youth risky behaviors. Am J Community Psychol. 2010;45(1-2):17-35.

4. Wilson EC, Garofalo R, Harris RD, Herrick A, Martinez M, Martinez J, et al. Transgender female youth and sex work: HIV risk and a comparison of life factors related to engagement in sex work. AIDS Behav. 2009;13(5):902-13.

5. Jackson CA, Henderson M, Frank JW, Haw SJ. An overview of prevention of multiple risk behaviour in adolescence and young adulthood. J Public Health (Bangkok). 2012;34(suppl_1):i31-40.

6. Shead NW, Derevensky JL, Gupta R. Risk and protective factors associated with youth problem gambling. Int J Adolesc Med Health. 2010;22(1):39.

7. Griffin KW, Botvin GJ. Evidence-Based Interventions for Preventing Substance Use Disorders in Adolescents. Child and Adolescent Psychiatric Clinics of North America. 2010.

8. Jongenelis $\mathrm{M}$, Pettigrew S, Lawrence D, Rikkers W. Factors associated with poly drug use in adolescents. Prev Sci. 2019;20(5):695-704. 
9. Ljubotina D, Galic J, Jukic V. Prevalence and risk factors of substance use among urban adolescents: questionnaire study. Croat Med J. 2004 Feb;45(1):88-98.

10. Fuller CM, Vlahov D, Arria AM, Ompad DC, Garfein R, Strathdee SA. Factors associated with adolescent initiation of injection drug use. Public Health Rep. 2016;

11. Nosratabadi M, Halvaiepour Z. Psychological determinants of drug abuse among male adolescents in Isfahan: A structural model. Int J Prev Med. 2019;10.

12. Karatay G, Baş NG. Factors affecting substance use and self-efficacy status of students in eastern Turkey. Cien Saude Colet. 2019;24:1317-26.

13. Palallo UD, Syafar M, Amiruddin R, Indar, Yani A. Effects of adolescent attitudes on forming intention to stop smoking. Int J Innov Technol Explor Eng. 2019;9(1).

14. Palallo UD, Syafar M, Amiruddin R, Indar, Yani A. The effect of life skill education on cigarette control in adolescents. Indian J Public Heal Res Dev. 2019;10(9).

15. Terzian MA, Andrews KM, Moore KA. Preventing Multiple Risky Behaviors among Adolescents: Seven Strategies. Washington; 2011.

16. Killianova T. Risky Behavior BT - Encyclopedia of Behavioral Medicine. In: Gellman MD, Turner JR, editors. (eds) Encyclopedia of Behavioral Medicine. New York, NY: Springer New York; 2013. p. 1692-3.

17. Ajzen. The theory of planned behavior. Organ Behav Hum Decis Process. 1991;50(2):179-211.

18. Foshee VA, Benefield T, Suchindran C, Ennett ST, Bauman KE, Karriker-Jaffe KJ, et al. The development of four types of adolescent dating abuse and selected demographic correlates. J Res Adolesc. 2009;19(3):380-400.

19. Heger JP, Brunner R, Parzer P, Fischer G, Resch $\mathrm{F}$, Kaess M. [Depression and risk behavior in adolescence]. Prax Kinderpsychol Kinderpsychiatr. 2014;63(3):177-99.

20. Wojtyla-Buciora P, Klimberg A, Kapka-Skrzypczak L, Diatczyk J, Urbaniak M, Ulatowska-Szostak E, et al. Monitoring risk behaviour in adolescent pupils regarding consumption of psychoactive substances. Ann Agric Environ Med. 2017 Jun;24(2):350-5.
21. Ammerman BA, Steinberg L, McCloskey MS. Risk-Taking Behavior and Suicidality: The Unique Role of Adolescent Drug Use. J Clin Child Adolesc Psychol. 2018;

22. Browning CR, Soller B, Jackson AL. Neighborhoods and adolescent health-risk behavior: an ecological network approach. Soc Sci Med. 2015 Jan;125:16372.

23. Keyes KM, Jager J, Hamilton A, O’Malley PM, Miech R, Schulenberg JE. National multi-cohort time trends in adolescent risk preference and the relation with substance use and problem behavior from 1976 to 2011. Drug Alcohol Depend. 2015 Oct;155:267-74.

24. Kellam SG, Wang W, Mackenzie ACL, Brown $\mathrm{CH}$, Ompad DC, Or F, et al. The impact of the Good Behavior Game, a universal classroom-based preventive intervention in first and second grades, on high-risk sexual behaviors and drug abuse and dependence disorders into young adulthood. Prev Sci. 2014 Feb;15 Suppl 1:S6-18.

25. Dougherty DM, Lake SL, Mathias CW, Ryan SR, Bray BC, Charles NE, et al. Behavioral Impulsivity and Risk-Taking Trajectories Across Early Adolescence in Youths With and Without Family Histories of Alcohol and Other Drug Use Disorders. Alcohol Clin Exp Res. 2015 Aug;39(8):1501-9.

26. Zebrak KA, Green KM. The role of young adult social bonds, substance problems, and sexual risk in pathways between adolescent substance use and midlife risky sexual behavior among urban African Americans. Psychol Addict Behav. 2017 Nov;31(7):828-38.

27. Yu J, Putnick DL, Hendricks C, Bornstein MH. Health-Risk Behavior Profiles and Reciprocal Relations With Depressive Symptoms From Adolescence to Young Adulthood. J Adolesc Health. 2017 Dec;61(6):773-8.

28. Cordova D, Alers-Rojas F, Lua FM, Bauermeister J, Nurenberg R, Ovadje L, et al. The Usability and Acceptability of an Adolescent mHealth HIV/STI and Drug Abuse Preventive Intervention in Primary Care. Behav Med. 2018;44(1):36-47.

29. Gart R, Kelly S. How Illegal Drug Use, Alcohol Use, Tobacco Use, and Depressive Symptoms Affect Adolescent Suicidal Ideation: A Secondary Analysis of the 2011 Youth Risk Behavior Survey. Issues Ment Health Nurs. 2015 Aug;36(8):614-20. 
30. Thombs DL, O’Mara R, Dodd VJ, Merves ML, Weiler RM, Goldberger BA, et al. Event-specific analyses of poly-drug abuse and concomitant risk behavior in a college bar district in Florida. J Am Coll Health. 2009;57(6):575-85.

31. Hops H, Ozechowski TJ, Waldron HB, Davis B, Turner CW, Brody JL, et al. Adolescent healthrisk sexual behaviors: Effects of a drug abuse intervention. AIDS Behav. 2011;15(8):1664-76.

32. Kann L, McManus T, Harris WA, Shanklin SL, Flint KH, Queen B, et al. Youth risk behavior surveillance - United States, 2017. MMWR Surveill Summ. 2018;

33. Campbell JA, Walker RJ, Egede LE. Associations between adverse childhood experiences, high-risk behaviors, and morbidity in adulthood. Am J Prev Med. 2016;50(3):344-52.

34. Negriff S. A pilot study examining risk behavior in facebook posts for maltreated versus comparison youth using content analysis. Child Abuse Negl. 2019;96(April):104091.
35. Brook DW, Brook JS, Rubenstone E, Zhang C, Finch SJ. A Longitudinal Study of Sexual Risk Behavior Among the Adolescent Children of HIVPositive and HIV-Negative Drug-Abusing Fathers. J Adolesc Heal. 2010;46(3):224-31.

36. Leung H, Ph D, Lin L, Ph D. Adolescent Sexual Risk Behavior in Hong Kong : Prevalence, Protective Factors, and Sex Education Programs. J Adolesc Heal. 2019;64(6):S52--S58.

37. Lee Y, Lee KS. Relationship between unhealthy weight control behaviors and substance use patterns among Korean adolescents: results from the 2017 national youth risk behavior survey. Public Health. 2019;174:56-64.

38. Whitesell M, Bachand A, Peel J, Brown M. Familial, social, and individual factors contributing to risk for adolescent substance use. J Addict. 2013/03/20. 2013;2013:579310. 